\title{
PENGARUH RETURN ON ASSET, RETURN ON EQUITY, NET PROFIT MARGIN, DAN EARNING PER SHARE TERHADAP HARGA SAHAM PADA PERUSAHAAN LQ45 YANG TERDAFTAR DI BURSA EFEK INDONESIA PERIODE 2014-2018
}

\author{
Bayu Takaful ${ }^{1}$, Risal Rinofah ${ }^{2}$, Mujino $^{3}$ \\ 1,2,3 Universitas Sarjanawiyata Tamansiswa \\ Jl. Kusumanegara No. 157, Muja Muju, Umbulharjo, Yogyakarta \\ E-mail: sayaadalahbayu@gmail.com
}

\begin{abstract}
INTISARI
Penelitian ini bertujuan untuk menguji pengaruh Return On Asset (ROA), Return On Equity (ROE), Net Profit Margin (NPM), dan Earning Per Share (EPS). Sampel yang diambil adalah 15 perusahaan LQ45 yang terdaftar di Bursa Efek Indonesia pada tahun 2014-2018 Teknik analisis menggunakan teknik purposive sampling. Hasil penelitian ini adalah Return On Asset (ROA) berpengaruh negatif dan tidak signifikan terhadap harga saham, Return On Equity (ROE) berpengaruh positif dan signifikan terhadap harga saham, Net Profit Margin (NPM) berpengaruh negatif dan signifikan terhadap harga saham, dan Earning Per Share (EPS) berpengaruh positif tidak signifikan terhadap harga saham, serta secara bersama-sama Return On Asset (ROA), Return On Equity (ROE), Net Profit Margin (NPM) Earning Per Share (EPS) berpengaruh signifikan terhadap harga saham.
\end{abstract}

Kata Kunci: Return On Asset (ROA), Return On Equity (ROE), Net Profit Margin (NPM), Earning Per Share (EPS), Harga Saham.

\section{ABSTRACT}

This study aims to examine the effect of Return on Asset (ROA), Return On Equity (ROE), Net Profit Margin (NPM), and Earning Per Share (EPS) on Stock Price. Samples taken were 15 LQ45 companies listed on the Indonesia Stock Exchange in 2014-2018. Analysis techniques using purposive sampling techniques. The results of this study are that the Return On Asset (ROA) has a negative and not significant effect on stock price, Return On Equity (ROE) has a positive and significant effect on stock prices, Net Profit Margin (NPM) has a negative and significant effect on stock prices, Earning Per Share (EPS) has a positive and not significant effect on stock prices, and together Return On Asset (ROA), Return On Equity (ROE), Net Profit Margin (NPM), and Earning Per Share (EPS) have a significant effect on stock prices.

Keywords: Return On Asset (ROA), Return On Equity (ROE), Net Profit Margin (NPM), Earning Per Share (EPS), Stock Prices

\section{PENDAHULUAN}

Saat ini pasar modal telah mengalami perkembangan yang sangat pesat serta memegang peran penting dalam mobilisasi dana dari masyarakat yang ingin berinvestasi di pasar modal. Investasi merupakan salah satu cara yang dilakukan untuk mendapatkan sejumlah keuntungan dengan cara menanamkan modal atau membeli asset berharga yang ditawarkan di pasar modal. Menurut (Hartono, 2014:5) Kegiatan investasi merupakan penundaan konsumsi sekarang untuk dimasukkan ke dalam aktiva produktif selama periode waktu tertentu. Saat ini bentuk investasi yang popular digunakan adalah dalam bentuk saham.

Return On Aset (ROA) digunakan untuk mengukur efektivitas suatu perusahaan dalam memanfaatkan aktiva yg dimilikinya. Semakin meningkatnya Return On Asset (ROA) maka kinerja sebuah perusahaan akan semakin baik, karena tingkat pengembalian yang diharapkan semakin tinggi (Hardiningsih dkk, 2002:86). Apabila nilai ROA yang dihasilkan 
dalam industri semakin kecil, maka mengindikasikan berkurangnya kemampuan manajemen dalam mengolah aktiva untuk menekan biaya dan meningkatkan pendapatan. Return On Equity (ROE) adalah rasio yang membandingkan antara laba setelah pajak dan modal sendiri atau modal saham yang digunakan dalam mengukur tingkat pengembalian atas investasi bagi para pemegang saham biasa atau pemilik modal (Putri, 2011). Menurut (Danarto Raharjo \& Dul Muid, 2013) semakin tinggi rasio ini maka akan semakin baik, karena memberikan tingkat pengembalian yang lebih besar kepada pemegang saham dan akan menjadi sinyal positif bagi investor dalam pengambilan keputusan membeli saham.

Net Profit Margin (NPM) adalah rasio profitabilitas yang menggambarkan seberapa besar kemampuan sebuah perusahan dalam menghasilkan tingkat penjualan tertentu (Hanafi, 2003). Apabila sebuah perusahaan dapat menghasilkan rasio NPM yang tinggi, maka perusahaan tersebut dapat dikatakan memiliki tingkat kinerja yang baik dan produktif. Jadi, dengan adanya peningkatan Net Profit Margin (NPM), maka akan mempengaruhi tingginya tingkat pengembalian return saham pada pihak investor. Earning Per Share (EPS) adalah rasio untuk mengukur keberhasilan sebuah manajemen prusahaan dalam usaha mencapai keuntungan bagi para pemiik saham. Earning Per Share (EPS) menggambarkan profitabilitas suatu perusahaan dalam setiap lembar saham (Darmadji \& Fakhruddin). Semakin tinggi nilai Earning Per Share (EPS) tentu saja akan menyebabkan semekin besarnya laba yang diperoleh dan kemungkinan akan terjadi peningkatan jumlah dividen yang diterima para pemegang saham dan secara bersamaan harga saham akan ikut berubah.

Adanya pasar modal di Indonesia saat ini ditandai dengan semakin banyaknya investor yang telah menanamkan modalnya dalam bentuk kepemilikan saham. Di Bursa Efek Indonesia perusahaan-perusahaan dikelompokkan menjadi beberapa sektor yaitu sektor yaitu sektor sumber daya alam, manufaktur, dan jasa. Ketiga sektor tersebut masih dikelompokkan lagi menjadi beberapa subsektor industri. selain dikelompokkan pada sektor dan sub sektor ada juga yang dikelompokkan dalam indeks LQ45, dimana didalmnya terdapat 45 perusahaan yang telah melalui proses seleksi dengan liquiditas tinggi serta beberapa kriteria lainnya. Secara garis besar perusahaan yang terdaftr di LQ45 memiliki sham yang sangat baik karena telah melalui proses seleksi sengingga menurut peneliti sangat menarik untuk di teliti.

Berdasarkan uraian diatas penelitian ini mengambil judul "Pengaruh Return On Asset (ROA), Return On Equity(ROE), Net Profit Margin (NPM), dan Earning Per share (EPS) terhadap Harga Saham pada Perusahaan LQ45 yang Terdaftar di Bursa Efek Indonesia Priode 2014-2018"

\section{TINJAUAN PUSTAKA DAN PENGEMBANGAN HIPOTESIS Return On Asset (ROA)}

Return On Asset (ROA) merupakan rasio laba bersih terhadap total aktifa yang mengukur pengembalian total aktiva setelah adanya bunga dan pajak. Return On Asset (ROA) sering disebut sebagai rentabilitas ekonomi yang merupakan perbandingan antara net income dengan total asaet yang digunakan perusahaan dalam menghasilkan laba.

\section{Return On Equity (ROE)}

Return On Equity (ROE) merupakan rasio yang mengukur pendapatan (income) perusahaan yang tersedia untuk para pemilik dan pemegang saham atas modal yang mereka telah investasikan. Rasio ini juga memperlihatkan sejauh mana kemampuan perusahaan dalam mengelola modalnya dengan efektif.

\section{Net Profit Margin (NPM)}

Menurut (Kasmir, 2008:200) Net Profit Margin (NPM) adalah ukuran keuntungan sebuah perusahaan yang membandingkan antara laba setelah bunga dan pajak dengan 
penjualan. NPM mencerminkan kemampuan perusahaan untuk memperoleh laba neto dari setiap penjualannya.

\section{Earning Per Share (EPS)}

Earning Per Share (EPS) adalah bentuk pemberian keuntungan yang diberikan kepada para pemegang saham dari setiap lembar saham yang dimiliki, rasio ini desebut juga sebagai pendapatan perlembar saham.

\section{Pengembangan Hipotesis}

Berbagai penelitian yang telah dilakukan terkait dengan harga saham yang berhubungan dengan variabel lainnya menunjukkan hasil yang berbeda-beda. Penelitian Ryan Perkasa Rimbani (2016) menunjukkan bahwa terdapat pengaruh yang signifikan kearah positif pada variabel ROE, EPS, dan NPM terhadap harga saham.

Fitri Herawati, Ronny Mardani dan M. Khoirul ABS, (2018) mendapat hasil penelitian bahwa ROA memiliki pengaruh positif dan signifikan terhadap harga saham serta NPM berpengaruh negatif dan tidak signifikan terhadap harga saham. Lain halnya dengan penelitian yang dilakukan oleh Neneng Tita Amalya, (2018) mengatakan bahwa ROE dan ROA berpengaruh tidak signifikan pada harga saham serta NPM berpengaruh signifikan terhadap harga saham.

Penelitian yang dilakukan oleh Hangga Pradika Mujiono (2017) menyatakan bahwa ROA memiliki pengaruh yang positif dan juga signifikan terhadap harga saham. Penelitian yang dilakukan oleh Hangga Pradika Mujiono (2017) mendapatkan hasil dimana terdapat pengaruh positif dan signifika variabel EPS terhadap harga saham.

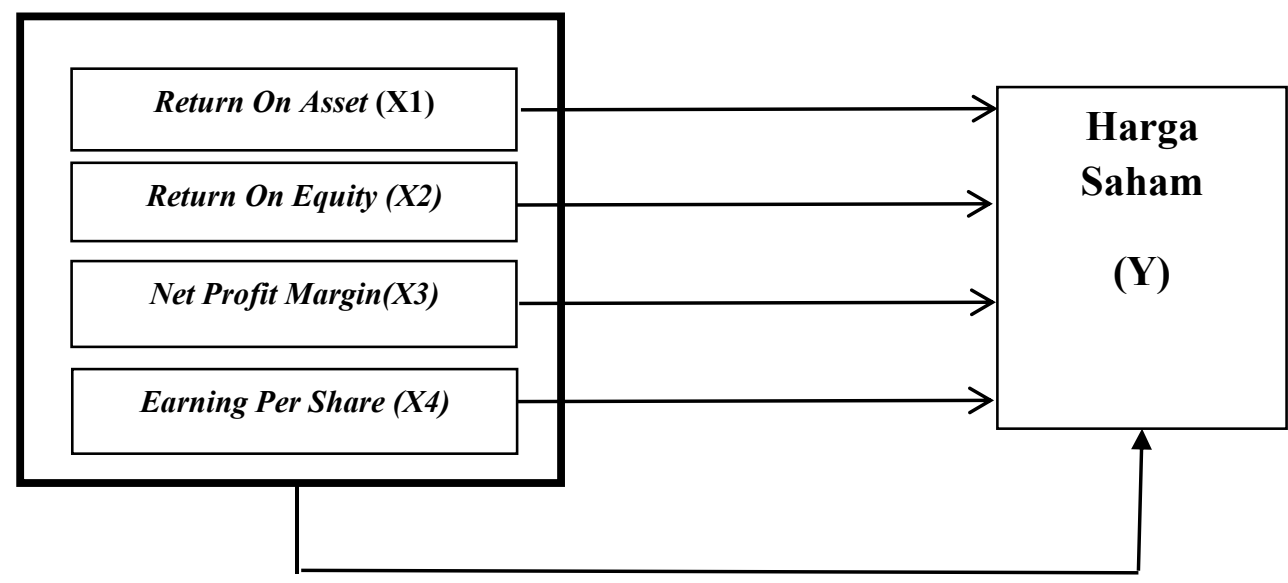

Gambar 1. Kerangka Penelitian

\section{METODE PENELITIAN}

\section{Sifat Penelitian}

Penelitian ini bersifat kuantitatif dengan menganalisa data-data sekunder. Penelitian kuantitaif adalah jenis penelitian yang menghasilkan penemuan-penemuan yang dapat diccapai (diperoleh) dengan menggunakan prosedur-prosedur stastistik atau cara-cara lain dari kuantifikasi (pengukuran) (Sujarweni, 2014:39). Penelitian ini menggunalan data sekunder yang diperoleh dari laporan keuangan tahunan pada perusahan LQ45 yang terdaftar di Bursa Efek Indonesia Priode 2014-2018 
Variabel Penelitian

Tabel 1 Definisi Operasional Variabel

\begin{tabular}{|c|c|c|}
\hline Variabel & Indikator & Skala \\
\hline ROA & Return On Asset $(R O A)=\frac{\text { Laba Setelah Pajak }}{\text { Total Aktiva }} X 100 \%=\cdots \%$ & Rasio \\
\hline ROE & Return On Equity $(R O E)=\frac{\text { Laba Bersih }}{\text { Total Ekuitas }} X 100 \%=\cdots \%$ & Rasio \\
\hline NPM & Net Profit Margin $(\mathrm{NPM})=\frac{\text { Laba Setelah Pajak }}{\text { Penjualan }} X 100 \%=\cdots \%$ & Rasio \\
\hline EPS & $\begin{array}{c}\text { Earning Per Share (EPS ) }=\frac{\text { Laba Setelah Pajak }}{\text { Jumlah Saham Beredar }} \times 100 \% \\
=\ldots \%\end{array}$ & Rasio \\
\hline
\end{tabular}

Populasi penelitian ini adalah perusahaan LQ45 yang terdaftar di Bursa Efek Indonesia priode 2014-2018 sebanyak 15 perusahaan. Pemilihan sampel penelitian ini dilakukan melalui metode purposive sampling. Metode purpose sampling yaitu metode peilihan sampel berdasarkan karakteristik populasi yang telah ditentukan.

Tabel 2 Sampel Perusahaan LQ45

\begin{tabular}{|c|c|c|}
\hline No & Kode & Nama Perusahaan \\
\hline 1. & ADHI & AdhiKarya (Persero) Tbk \\
\hline 2. & ADRO & Adaro Energy Tbk \\
\hline 3. & AKRA & AKR Corporindo Tbk \\
\hline 4. & BBRI & Bank Rakyat Indonesia (persero Tbk) \\
\hline 5. & BSDE & Bumi Serpong Damai Tbk \\
\hline 6. & JSMR & Jasa Marga (persero) Tbk \\
\hline 7. & KLBF & Kalbe Farma Tbk \\
\hline 8. & LPKR & Loppo Karawaci Tbk \\
\hline 9. & $\mathrm{MNCN}$ & Media Nusantara Citra Tbk \\
\hline 10. & PGAS & Perusahaan Gas Negara Tbk \\
\hline 11. & PTBA & Bukit Asam Tbk \\
\hline 12. & РТРP & Pembangunan Perumahan Tbk \\
\hline 13. & TLKM & Telekomunikassi Inoonesia Tbk \\
\hline 14. & WIKA & Wijaya Karya (persero) Tbk \\
\hline 15. & WSKT & Waksita Karya (persero) Tbk \\
\hline
\end{tabular}

\section{HASIL DAN PEMBAHASAN \\ Pengujian Asumsi Klasik}

Tabel 3 Uji Normalitas

One - Sample Kolmogorov - Smirnov Test

\begin{tabular}{l}
$\begin{array}{l}\text { Unstandardized } \\
\text { Residual }\end{array}$ \\
\hline Asymp. Sig. (2-tailed) \\
\hline a. Test distribution is Normal \\
b. Calculated from data \\
Sumber: Data Stastistik Diolah dengan SPSS 18
\end{tabular}


Berdasarkan tabel di atas menunjukan bahwa tingkat signifikansi sebesar 0,244 yang berarti lebih besar dari 0,05. Artinya hasil pengujian Kolmogrof-Smirnov berdistribusi normal.

Tabel 4 Hasil Uji Multikolineritas

\begin{tabular}{cccc}
\hline Variabel Independen & Tolerance & VIF & Keterangan \\
\hline (Constant) & & & \\
ROA & 0,371 & 2,695 & Tidak Terjadi Multikolinearitas \\
ROE & 0,295 & 3,387 & Tidak Terjadi Multikolinearitas \\
NPM & 0,709 & 1,411 & Tidak Terjadi Multikolinearitas \\
EPS & 0,599 & 1,669 & Tidak Terjadi Multikolinearitas \\
\hline
\end{tabular}

a. Variabel dependen : LN_Z

Sumber : Data Statistik diolah dengan SPSS 18

Dalam tabel diatas menunjukkan hasil semua nilai tolerance diatas 0,10 dan semua VIF dibawah 10 yang berarti terjadi masalah multikolineritas dikarenakan adanya korelasia antara 2 variabel.

Tabel 5 Hasil Uji Autokorelasi

\begin{tabular}{lcccrc}
\hline Model & R & R Square & $\begin{array}{c}\text { Adjusted R } \\
\text { Square }\end{array}$ & $\begin{array}{c}\text { Std. Error of } \\
\text { the Estimate }\end{array}$ & Durbin-Watson \\
\hline 1 &, $374^{\text {a }}$ &, 140 &, 090 & 905,41411 & 1,868 \\
\hline Sumber : Data Statistik diolah dengan SPSS 18 & & &
\end{tabular}

Dalam metode Durbin-Waston suatu data dapat dinyatakan tidak terjadi autokorelasi yaitu apabila " $\mathrm{du}<\mathrm{d}<4$-du". Nilai du dapat diperoleh melalui tabel Durbin-Waston sesuai dengan jumlah sampel pada data kita. dari table diatas dapat kita ketahui nilai dari Durbin-Waston (nilai d) yaitu 1,868. Dari sampel yang berjumlah 75 maka didapat nilai du dan dl sebagai berikut :

Tabel 6 Durbin-Waston

\begin{tabular}{ccccc}
\hline D & Dl & Du & 4-dl & 4-du \\
\hline 1,868 & 1,5151 & 1,7390 & 2,4849 & 2,261 \\
\hline
\end{tabular}

Dari data diatas dapat dilihat bahwa $\mathrm{du}(1,7390)<\mathrm{d}(1,868)<4-\mathrm{du}(2,261)$ maka dapat disimpulkan bahwa tidak terjadi autokorelasi.

Tabel 7 Hasil Uji Heteroskedastisitas

\begin{tabular}{ccccc}
\hline Model & R & R Square & Adjusted R Square & $\begin{array}{c}\text { Std.erorof the } \\
\text { estimate }\end{array}$ \\
\hline 1 &, 293 &, 086 & 0,33 &, 34583 \\
\hline Sumber: Data stastistik diolah dengan SPSS 18 & &
\end{tabular}

Cara melakukan uji white yaitu dengan mencari terlebih dahulu nila chi square hitung yaitu dengan rumus N X R square $(0,086$ X $75=6,45)$ lalu ,stelah mendapatkan nilai chi square hitung kita harus mencari nilai chi square table dengan rumus $\mathrm{Df}=\mathrm{k}-1 \quad(4-1=3)$ dan perhatikan table chi square $(7,815)$.

Dasar pengambilan keputusan pada uji white yaitu apabila nilai chi square hitung lebih kecil dari nilai chi square table maka tidak terjadi heterokedastisitas. Padaa hasil diatas dapat 
dilihat bahwa nilai chi square hitung ternyata lebih kecil dari nilai chi square table sehingga dapat disempulkan bahwa tidak terjadi heterokedastisitas.

\section{UJI HIPOTESIS}

Tabel 8 Hasil Uji Koefesien

\begin{tabular}{cc}
\hline Model & Adjusted R Square \\
1 & 0,332 \\
\hline Sumber : Data stastistik & diolah dengan SPSS 18
\end{tabular}

Berdasarkan tabel diatas diperoleh nilai Adjusted R Square 0,365 atau sama dengan 33,2\% artinya sekitar $67,8 \%$ dipengaruhi oleh variable lain yang tidak dimasukkan dalam model regresi ini.

Tabel 9 Hasil Uji Hipotesis Simultan

\begin{tabular}{lccc}
\hline & Model & F & Sig \\
\hline Regression & & 10.221 & $0,000^{\mathrm{a}}$ \\
Residual & & \\
Total & & \\
\hline
\end{tabular}

Sumber : Data stastistic diolah dengan SPSS 18

Berdasarkan tabel dapat diketahui nilai F-hitung 10,211 dan tingkat signifikansi dari nilai $\mathrm{F}$ adalah sebesar 0,000, karena tingkat signifikansi lebih kecil dari 0,05\% yang berarti $\mathrm{H} 0$ ditolak dan Ha diterima, artinya bahwa variabel ROA, ROE, NPM, dan EPS memiliki pengaruh signifikan secra simultan terhadap harga saham.

Tabel 10 Hasil Uji Parsial

\begin{tabular}{|c|c|c|c|}
\hline Model & B & $\mathbf{T}$ & Siq \\
\hline Constant & & & \\
\hline ROA &,- 161 & $-1,032$ & ,306 \\
\hline ROE &, 589 & 3,372 & 001 \\
\hline NPM &,- 311 & $-2,753$ & 008 \\
\hline EPS &, 232 & 1,894 &, 062 \\
\hline
\end{tabular}

Sumber: Data statistik diolah dengan SPSS

\section{Pengaruh Retrun On Asset (ROA) terhadap Harga Saham}

Berdasarkan uji secara persial diperoleh nilai beta -0,161 dengan signifikansi 0,306 lebih besar dari taraf signifikansi yaitu $0,05(0,306>0,05)$, karena nilai signifikansi Retrun On Asset (ROA) lebih besar dari 0,05 maka hipotesis ditolak. Pada penelitian ini menunjukan jika Retrun On Asset (ROA) memiliki pengaruh yang negatif dan juga tidak signifikan terhadap harga saham. Hasil ini juga diperkuat dengan jurnal penelitian Elis Darnita (2014). Koefesien regresi untuk ROA menunjukkan kearah negatif, artinya jika ROA naik maka harga saham turun. Jadi besar kecilnya ROA tidak serta merta mempengaruhi tinggi rendahnya harga saham. Artinya perusahaan kurang maksimal dalam pengelolaan asset untuk menghasilkan laba. Kondisi ini, menggambarkan bahwa kemampuan perusahaan dalam memperoleh laba dan untuk mengendalikan seluruh biaya-biaya operasional maupun non oprasional belum terlalu baik. Tidak signifikannya variabel ini juga disebabkan adanya faktor lain diluar analisis rasio yang dapat mempengaruhi harga saham di pasar modal, seperti 
adanya perubahan tingkat inflasi, suku bunga, memburuknya perekonomian global yang mempengaruhi perekonomian domestik, dan faktor lainnya. Hal ini sesuai dengan penelitian yang telah dilakukan oleh Abid Djazuli (2006) dan penelitian oleh Mukhtaruddin dan Deesmon (2007) yang menunjukkan bahwa ROA tidak memiliki pengaruh yang signifikan terhadap harga saham.

\section{Pengaruh Return On Equity (ROE) Terhadap Harga Saham}

Berdasarkan uji secara persial diperoleh nilai beta 0,589 dengan signifikansi 0,001 lebih kecil dari taraf signifikansi yaitu $0,05(0,001>0,05)$, karena nilai signifikansi Return On Equity (ROE) lebih besar dari 0,05 maka hipotesis diterima. Pada penelitian ini menunjukan jika ROE memiliki pengaruh yang positif dan juga signifikan terhadap harga saham. Hal ini sesuai dengan teori yang dikemukakan oleh Kasmir (2013:204) yang mengatakan bahwa ROE merupakan rasio yang digunakan dalam mengukur kemampuan perusahaan dalam menghasilkan laba yang tersedia badi para pemegang saham perusahaan atau untuk mengetahui bersarnya kembalian yang diberikan perusahaan untuk setiap rupih modal dari para pemilik. Rasio ini juga menunjukkan efisiensi perusahaan dalam menggunakan modal sendiri.semakin baik rasio ini maka akan semakin baik pula untuk prusahaan, yang artinya perusahaan akan semakin kuat. Pernyataan ini juga sesuai dengan penelitian Dinda Alfianti Aldini dan Sonja Andarini (2017).

\section{Pengaruh Net Profit Margin (NPM) Terhadap Harga Saham}

Berdasarkan uji secara persial diperoleh nilai beta -0,311 dengan signifikansi 0,008 lebih kecil dari taraf signifikansi yaitu 0,05 $(0,008>0,05)$, nilai signifikansi Net Profit Margin (NPM) lebih kecil dari 0,05 namun nilai t hitung bertanda negatif maka hipotesis ditolak. Pada penelitian menunjukkan bahwa NPM memiliki pengaruh yang negatif dan juga signifikan terhadap harga saham. NPM memiliki dua unsur yaitu laba bersih setelah pajak dan juga pendapatan atau penjualan bersih. NPM memiliki pengaruh yang negatif dan signifikan. Hal ini dapat diakibatkan oleh unsur dasar dari NPM itu sendiri, di mana investor biasanya akan lebih memperhatikan angka penjualan bersih atau omzet dari perusahaan pada saat akan mengambil keputusan untuk berinvestasi. Meningkatnya penjualan yang tidak diikuti meningkatnya laba bersih dapat menurunkan persentasi NPM. Laba bersih sendiri dipengaruhi oleh beban serta biaya yang pada kenyataannya terus mengalami peningkatan. Pernyataan ini juga diperkuat dengan jurnal penelitian Gerald Edsel Yermia Egam, Ventje Ilat dan Sonny Pangerapan (2017).

\section{Pengaruh Erning Per Share (EPS) terhadap Harga Saham}

Berdasarkan uji secara parsial diperoleh nilai beta 0,232 dengan signifikansi 0,062 lebih besar dari taraf signifikansi yaitu 0,05 $(0,062>0,05)$, karena nilai signifikansi Earning Per Share (EPS) lebih besar dari 0,05 maka hipotesis ditolak. Pada penelitian ini menunjukan bahwa EPS memiliki pengaruh positif dan tidak signifikan terhadap harga saham. Nilai positif yang didapat menunjukan bahwa terdapat pengaruh terhadap harga saham dimana semakin besar nilai EPS maka harga saham akan naik. Namun apabila EPS mengalami penurunan makan hal sebaliknya akan terjadi. Penurunan dapat terjadi di perusahaan manapun dengan penyebab yang sangat beragam mulai dari faktor internal maupun eksternal perusahaan. Jika sebuah perusahaan belum bisa menstabilkan kondisi naik turun tersebut maka akan membuat investor berfikir apakah EPS perusahaan tersebut akan selalu stabil atau bahkan dapat turun secara tiba-tiba dan akan merugikan para pemegang saham. Pernyataan ini juga diperkuat dengan jurnal penelitian Takarini \& Rosita (2011). 


\section{PENUTUP}

Kesimpulan

Dari hasil penelitian dapat disimpulkan bahwa ROA memiliki pengaruh yang negatif dan tidak signifikan terhadap harga saham, ROE memiliki pengaruh yang positif dan signifikan terhadap harga saham, NPM memiliki pengaruh yang negatif dan signifikan terhadap harga saham, dan EPS memiliki pengaruh yang positif dan tidak signifikan terhadap harga saham.

\section{Saran}

Penelitian berikutnya disarankan lebih banyak menggunakan jumlah sampel dan menambah periode pengamatan serta mempertimbangkan variabel lainnya. Bagi Perusahaan harus lebih memaksimalkan Kinerja mereka, dalam penelitian ini yang terutama harus di tingkatkan adalah pada vatiabel Net Profit Margin (NPM) dimana naiknya tingkat penjualan haruslah diikuti dengan meningkatnya laba bersih. Selain itu perusahaan harus memperhatikan dan meningkatkan kinerja pada variabel Retrun On Asset (ROA) dan Earning Per Share (EPS) yang pada penelitian ini tidak berpengaruh signifikan. Bagi para investor dalam mengambil keputusan dalam berinvestasi, investor perlu menganalisis kinerja dan prospek saham terlebih dahulu. Perhatikan semua aspek keuangan, dan juga tren harga saham dari perusahaan tersebut.

\section{DAFTAR PUSTAKA}

Aldini, D. A., \& Andarini, S. (2017). Pengaruh Profitabilitas Terhadap Harga Saham Pada Perusahaan Makanan dan Minuman Yang Terdaftar di Bursa Efek Indonesia. Jurnal Bisnis Indonesia, 8(1).

Amalya, N. T. (2018). Pengaruh return on asset, return on equity, net profit margin dan debt to equity ratio terhadap harga saham. Jurnal SEKURITAS (Saham, Ekonomi, Keuangan dan Investasi), 1(3).

Darnita, E. (2014). Pengaruh Return On Asset, Return On Equity, Net Profit Margin, dan Earninng Per Share Terhadap Harga Saham Pada Perusahaan Food dan Bevereges yang Terdaftar di Bursa Efek Indonesia Priode 2008-2012. Fakultas Ekonomi Dan Bisnis Manajemen Universitas Dian Nuswantoro Semarang.

Djazuli, A. (2006). Pengaruh EPS, ROI, dan ROE Terhadap Perubahan Harga Saham Pada Perusahaan Sektor Manufaktur Pada Bursa Efek Jakarta (BEJ). Fordema, 6(1), 51-62.

Egam, G. E., Ilat, V., \& Pangerapan, S. (2017). Pengaruh Return on Asset (ROA), Return on Equity (ROE), Net Profit Margin (NPM), dan Earning Per Share (EPS) terhadap Harga Saham Perusahaan yang Tergabung dalam Indeks LQ45 di Bursa Efek Indonesia Periode Tahun 2013-2015. Jurnal EMBA: Jurnal Riset Ekonomi, Manajemen, Bisnis dan Akuntansi, 5(1).

Hanafi, M. (2003). Analisis Laporan Keuangan (Edisi satu). UPP AMP YKPN.

Hardiningsih, P., Suryono, C. A., \& Chariri, A. (2002). Pengaruh Faktor Fundamental dan Risiko ekonomi Terhadap Return Saham pada Perusahaan bursa Efek Jakarta : Studi Kasus Basic Industry and Chemical. Jurnal Strategi Bisnis.

Hartono. (2014). Teori Portofolio dan Analisis Investasi . BPFE

Herawati, F., Mardani, R. M., \& ABS, M. K. (2018). Pengaruh Debt To Equity Ratio (Der), Return On Asset (Roa), Return On Equity (Roe), Dan Net Profit Margin (Npm) Terhadap Harga Saham. Jurnal Ilmiah Riset Manajemen, 7(9).

Kasmir. (2008). Analisis Laporan Keuangan. PT Raja Grafindo Persada Kasmir. (2013). Analisis Laporan Keuangan. PT Raja Grafindo Persada Mukhtaruddin, \& Deesmoon. (2007). Pengaruh Return On Asset, Return On Equity, Return 
On Invesment, Debt To Equity Ratio, dan Book value terhadap perusahaan Properti di Bursa Efek Jakarta. Jurnal Penelitian Dan Pengembangan Riset Akutansi , 1(1).

Mujiono, H. P. (2017). Pengaruh CR, DER, ROA, dan EPS Terhadap Harga Saham Food and Beverages. Jurnal Ilmu dan Riset Manajemen (JIRM), 6(3).

Putri, A. (2012). AnalisisPengaruh ROA, EPS, NPM, DER, dan PBV terhadap Return Saham.. Diponegoro Business Review, 1.

Raharjo, D., \& Muid, D. (2013). Analisis Faktor-Faktor Fundamental Rasio Keuangan Terhadap Perubahan Harga Saham. 2, 444-454.

Rimbani, R. P. (2016). Analisis pengaruh roe, eps, pbv, der, dan npm terhadap harga saham pada perusahaan real estate dan property di bursa efek indonesia (bei) periode 2011-2013. Jurnal bisnis dan manajemen, 53(12).

Sujarweni, V. W. (2014). Metodologi penelitian keperawatan.

Takarini, N., \& Rosita, F. (2011). Dampak roa, der dan saham kepemilikan publik terhadap kelengkapan pengungkapan laporan keuangan di Bursa Efek Indonesia. In Prosiding Seminar Nasional Manajemen Teknologi XIII. 